\title{
Breathing Fire into Landscapes that Burn: Wildfire Management in a Time of Alterlife
}

\author{
Alex Zahara \\ MEMORIAL UNIVERSITY OF NEWFOUNDLAND
}

\begin{abstract}
Across the globe, settler nation-states are being forced to contend with the large-scale ecological and social disruptions caused by settler colonialism. Wildfires are a charismatic example of this: when anthropogenic climate change combines with colonial forest management practices, wildfires act in ever changing ways with often violent and uneven impacts to human and nonhuman life. In a context of environmental change, managers, fire ecologists, and politicians alike are increasingly looking to reintroduce fire as a way of restoring "natural" forest landscapes while reducing fire suppression costs. In this paper, I examine one such policy of fire reintegration, in what is currently the Canadian province of Saskatchewan, the homelands of more than 50,000 Indigenous people (Cree, Dakota, Dene, Métis) who live in the province's Boreal Forest region. In 2004, the Province implemented a controversial policy that locals colloquially refer to as "Let-it-Burn," where fires are allowed to burn until they encroach upon something designated of "value" (typically human life, community structures, public infrastructure, and commercial timber). While wildfire managers, scientists, and politicians alike consistently advocate for policies of fire-reintegration as ecologically-sound and financially responsible ways forward with fire management, many locals have argued that "Let-it-Burn" is a direct affront to Indigenous sovereignty, destroying contemporary forest landscapes and rebuilding them through state-sanctioned settler values. Breathing fire back into landscapes that burn is a peculiar solution that at once acknowledges and erases the effects of fire's removal through policies of restoration that risk ignoring the ongoingness of life in forested areas. Through interviews and archival and ethnographic fieldwork, this paper traces the history of the province's "Let-it-Burn" policy, asking the question, "how to burn well in compromised lands?" As a way forward with fire reintegration (or not), I highlight the necessity of Indigenous partnership, leadership, and direction within fire management practices on Indigenous territory, which may include fire suppression. This paper adds to STS scholarship on ecological ruination and alterlife, arguing that wildfire management practices are likely to cause harm so long as the effects of settler colonialism are placed in the past and Indigenous rebuilding is erased.
\end{abstract}

'Alex Zahara, Email: ardz76@mun.ca

Copyright (C) 2020 (Alex Zahara). Licensed under the Creative Commons Attribution Non-commercial No Derivatives (bync-nd). Available at estsjournal.org. 


\section{Keywords}

wildfire; canada; alterlife; forest management; settler colonialism

\section{Introduction: Fire Management in Late Industrialism}

I came to studying wildfires because my lungs were itchy. I grew up in a city called Prince Albert (pop. 40,000), or kistahpinanihk as it is called in Cree-the "meeting place," wedged between agricultural land and prairies to the south and the boreal forest to the north. It is located on Treaty 6 territory, the traditional lands of Cree (Plains, Swampy, Rocky, Woodland), Dene, Dakota, and Métis people, in an area that is currently known as the province of Saskatchewan, Canada. As is increasingly the case globally, summer days in Prince Albert are often characterized by a low glowing orange haze as wildfire smoke blocks sunlight. This "fifth season," as environmental organizations like 350.org have dubbed it, has considerable effects. During smoke events, hospitalization rates increase, particularly among infants, asthmatics, those with chronic lung disease, and the elderly (Gan et al. 2017; Le et al. 2014). It's also hard on the psyche. Days pass by and direct sunlight is hidden out of reach by clouds of smoke. People are agitated and they're worried. Many try not to leave their houses.

Growing up in Prince Albert, my lungs were also itchy', but not like this: when the winds blew southerly, the smell of sulfur dioxide from the local pulp mill would fill the city. Some people said that scent was the smell of money, and maybe they were right. In the late 1990s, due to provincial and industry investments, forestry revenue was expected to double to nearly $\$ 16$ Billion CAD annually - not bad for a province of just over one million people. Headlines in the (now defunct) La Ronge Northerner set the tone for forestry expectations at the time, joyfully declaring "Forestry doubles" and "It doesn't get much bigger!" ${ }^{3}$ Yet in 2006, forestry giant Weyerhaeuser closed the province's largest pulp mill, causing nearly 4000 people to lose their jobs. My high school English teacher warned that Prince Albert was going to become a ghost town, but it didn't. The city persisted. Folks moved on, many taking fly-in, fly-out jobs in the neighboring province of Alberta, mining bitumen at Cold Lake or further north to the oil sands at Fort McMurray. I remember it was easier to breathe, then. Toxicity, apparently, had been redistributed.

Or had it? At the same time that the province's forestry industry collapsed, a new wildfire management strategy had just been put forward by the Province. Saskatchewan Environment-the provincial department that oversees both forestry and forest fires-was increasingly becoming concerned with the ecological effects and resource costs stemming from nearly a century of wildfire suppression. Indeed, as is the case in other settler states, when Europeans and Euro-Canadians began settling Saskatchewan, they understood fire as both

2 When I say itchy, I'm describing my own personal experiences of having asthma. Asthma symptoms present themselves in different ways for different people, often due to environmental factors (see Kenner 2018). In Prince Albert, this includes wildfire smoke

${ }_{3}^{3}$ The La Ronge Northerner (1999). April 27th, 45 (17). Northern Saskatchewan Archives, \#NSA 050. 
harmful and dangerous (Christianson 2015; Neale 2018; Smith 2020). Indigenous practices of using fire, which are and were deeply connected to place', were outlawed by settler government agencies, framed as wild or wasteful and replaced with state-led fire suppression (Pyne 2007). In Saskatchewan, as elsewhere, fire suppression efforts were explicitly tied to settler colonial objectives. During the Great Depression of the 1930s, the Province increased fire suppression efforts to encourage a northward expansion of settlers into forested areas; they were incentivized to engage in a mixed forestry-agriculture economy and used fire to clear the land to allow for agriculture and mineral prospecting (Massie 2010). Following World War II, fire suppression efforts increased substantially as the then socialist government sought to "claim [] most of Saskatchewan's forest resources for the people of the province" (Quiring 2004, 167, my emphasis). Yet at the same time as fire suppression increased, Indigenous northerners were both sought out and actively began seeking out work as wildland firefighters-an occupation and expertise that developed over generations and persists in the province today.

By at least the 1990s, however, the effects of fire suppression were beginning to show. Insects and disease outbreaks were harming commercial timber. Megafires, caused by forests overdue to burn, were outstripping provincial wildfire management resources. Coinciding with their renewed interest in forestry, the Province began developing a plan for fire's reintegration, where, in non-commercially viable areas of the forest, wildfires would be monitored and allowed to burn naturally - or at least until they encroached on something designated as "value." Beginning in 2003, the Province officially implemented a policy of managing rather than suppressing fire-one that northerners quickly dubbed "Let-it-Burn." Crucially, "Let-it-Burn" differs from other forms of fire reintegration, such as prescribed or Indigenous cultural burning, which rely on deliberately set, planned, low intensity fires. According to the Northern Trappers Alliance (2014), the "Let-it-Burn" policy has "decimated wildlife and destroyed cabins [and] has had a serious impact on [trappers'] ability to make a living and thrive in a culturally sustainable way in their own home territory" (n.p.). In a context of unknown and changing ecological conditions, vast firefighting expertise, and deep knowledge and relations to the land, many Indigenous and northern leaders consistently call for more fire suppression as opposed to less (PAGC 2018; New North 2013). And while wildfire's reintroduction is being advocated for globally by scientists and social scientists alike, I argue it is necessary to remain reflexive of how, whether, and on whose terms fire is reintroduced.

\footnotetext{
4 Moreover, Indigenous cultural burns are rooted in specific reciprocal relations to land. For important work on this, see Kimmerer and Lake 2002; Lake et al. 2017; Lewis et al. 2018; Norgaard 2019; Bourke et al. 2020. I would also recommend Métis scholar Amy Cardinal Christianson's podcast series "the Good Fire" for conversations with Indigenous people engaged in cultural burning globally (Your Forest 2019). This paper is not about cultural burning, but about state-led practices of fire's reintegration and their relation to settler colonialism.

"A shift towards wildfire "management" rather than suppression is representative of a "paradigm shift" taking place within wildfire agencies, globally. As fire ecologist, Timothy Ingalsbee $(2017,557)$ writes, "a paradigm shift has been unfolding in the wildland fire community that seeks to restore fire ecology processes across broad landscapes. This would involve managing rather than aggressively suppressing large fires."
} 
According to Citizen Potawatomi philosopher Kyle Powys Whyte (2018), settler colonialism may be understood as a process of ecological disruption, "a form of domination that violently disrupts human relationships with the environment" (125), whereby "settler ecologies have to be inscribed into indigenous ecologies" (Whyte 2016a, 68). Because settler colonialism is an ongoing structure and process (Wolfe 1999), I suggest this disruption occurred first through fire's suppression and then more recently via "Let-it-Burn." In the context of late industrialism, then, in which "the levee has broken, retention walls have failed...disaster[s] are everywhere, eminent and normal" (Fortun 2014, 410), I argue that the uneven "failures" of wildfire management that impact Indigenous life are actually the "success" of settler colonial systems.

In this paper, I ask the question: "how to burn well in ecologically compromised lands?" In suggesting a way forward, I take up Métis STS scholar and historian Michelle Murphy's (2017) concept of alterlife. Alterlife, as Murphy suggests, takes place both through, in spite of, and against settler colonialism's ecological ruptures. It "embraces impure and damaged forms of life, pessimistically acknowledging ongoing violence, living within and against the worlds technoscience helped make. Alterlife is resurgent life, which asserts and continues nonetheless" (500). Viewed through the framework of alterlife, the northern boreal forest may be seen as a site that is "challenged by violent infrastructures, but also holding capacities to alter and be alteredto recompose relations to land and sociality... to survival and persistence, to undo some forms of life and be supported by others" (Murphy 2018, 117). In this sense, fire is (and has perhaps always been) a particularly relevant process for understanding and enacting alterlife. As STS scholar Timothy Neale and others (2019) put it, "Fire is conjunctural, durational and transformative" (115), a highly social process "that troubles any distinction between nature and culture, as fire is continuously shown to be a process steeped in, and capable of impacting the social context in which it unfolds" (Sutherland 2019, 785; Pyne 1997). That is to say, fire, and the particular relations it enables, are always informed by the systems and structures through which it is embedded.

This paper is my examination, as a settler scholar from kistahpinanihk/Prince Albert, of the settler colonial logics and practices that have guided Saskatchewan's policy of fire reintegration, known locally as "Let-it-Burn." As Indigenous scholars have noted, legacies of colonial extraction, misappropriation, interpretation, and abuse condition the relations through which research, including-and perhaps especially research focused on colonial injustices-is enacted (Smith 2012; Tuck 2009). It is this settler colonial context in which this research takes place and that I'm accountable to. Accordingly, while I hope this research will resonate with common STS topics of ecological ruination (Tsing 2015; Haraway 2016) and controversy (Wynne 2006; Jasanoff 2003), I draw primarily from Indigenous studies and STS scholars, as well as local practitioners, who have theorized relations produced through settler colonialism's ecological disruptions and harm often in the context of broader research ethics (Todd 2017; Konsmo and Recollet 2019; Liboiron 2021). To this end, this paper's focus is to "study up", to examine larger systems and settler colonial structures that inform wildfire management. It is therefore not a source of traditional knowledge, theory, or law, which belongs to specific Nations. However, with invitation, I have interviewed a number of First Nations and northern community officials 
with expertise on the workings, context, and effects of "Let-it-Burn."' Their shared expertise was generous, and I hope this paper will stand with their understandings, goals, and interests (cf TallBear 2014).

In this paper, I examine the "Let-it-Burn" policy of fire reintegration, which I understand as a "settler fire regime." In doing so, I take as my starting point that the "Let-it-Burn" policy exists (though it is often denied), and in doing so I trace the origins of the policy beginning in the early 1990s. Through archival and ethnographic research at the Province's Wildfire Management Branch, I show that the policy is built on two, sometimes overlapping ideas: first, that the Province can and should identify and protect "Values-at-Risk" on behalf of northern communities; and second, that practices of "Let-it-Burn" constitute a "natural" ecological process. After this, I follow the work of Indigenous and settler colonial studies STS scholars that have argued that settler colonialism is an ongoing structure premised on the severing of Indigenous ecologies and social relations (Whyte 2016a; Liboiron 2018). I show that two ideas through which "Let-it-Burn" is premised actively remake human-forest relations by, first, promoting seemingly "universal" values based on state economic interests and private property, and second, framing "Let-it-Burn" as a "natural" process, as opposed to one built upon compounding cycles of ecological change, disruption, and rebuilding. As a way forward with fire reintegration (or not), I highlight the necessity of Indigenous partnership, leadership, and direction within fire management practices on Indigenous territory. Doing so is necessary to respect the alterlives already built, and to divest supposedly "new" ecological paradigms from wildfire strategies premised on continued settler colonialism.

\section{The Making of "Let-it-Burn"}

The "Let-it-Burn" policy does not exist. A policy of differential zoning_of monitoring rather than suppressing fires, contingent on their proximity to a "value" - does. While the distinction may be semantic, it is one that has been repeated since the Province laid out the policy in its 2003 Fire and Forest Insect and Disease Management Policy Framework. As the Framework itself states, "This is not a 'let burn' policy." "The distinction," the authors suggest, "will be to link decisions to

\footnotetext{
" This research proposal was initially presented with invitation at the New North: Annual Mayor and Councillor meeting in November 2017, and research was developed through ongoing consultation with the Chief Executive Officer of the New North: Saskatchewan Association of Northern Communities and members of the Prince Albert Grand Council- Wildfire Management Task Force. I am thankful to members of the Task Force who encouraged me to interview key First Nations government officials and workers. Government officials spoke to me as experts in agency wildfire management and therefore this is reflected in the type of language used throughout this paper, which may not resonate with other contexts. Some of these participants were settlers while others were Indigenous. All interviewees reviewed and were permitted to amend and edit interview transcripts, including those from the provincial Wildfire Management Branch. Members of the Task Force and the Chief Executive Officer from the New North reviewed and provided comments on two summaries of this paper prior to publication. Research was approved by Memorial University's Interdisciplinary Committee on Ethics in Human Research (\#20181298AR).
} 
allow a fire to burn with 'values-at-risk' and the land and resource management objectives" (Saskatchewan Environment 2003, 28). Interestingly, since the policy first began, discussions about how, what, and on whose terms fires should be managed have largely been sidelined by the provincial government's continued assurance that a "Let-it-Burn" policy does not exist (Figures $1 \& 2$ ).

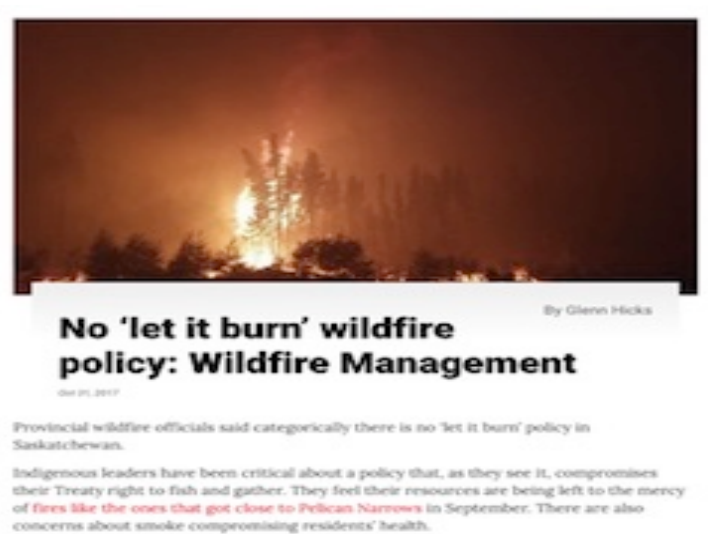

Figure 1: Screen shot from the Saskatoon StarPhoenix (2015).

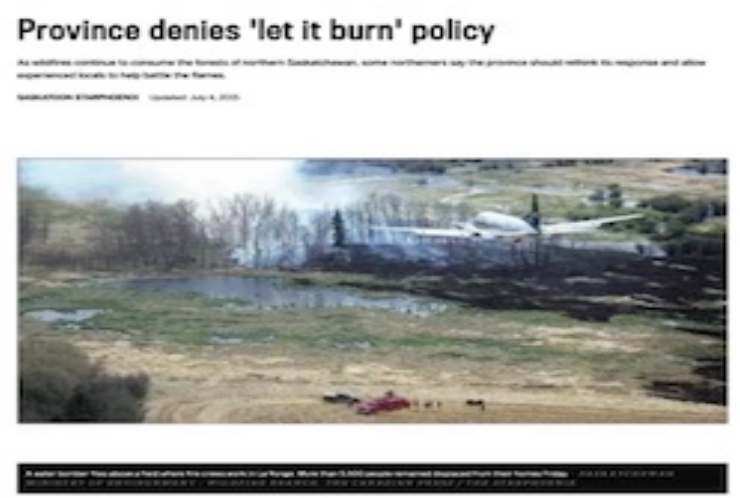

Figure 2: Screen shot from CBC News (Hicks 2017).

"For example, at a Standing Committee on the Economy meeting held November 21, 2006, Member of the Legislative Assembly, Glen Hart, raised the issue of "the so-called let-it-burn policy" for causing "a great deal of concern for a number of our communities in the North." The Minister of Environment, John Nilson, dismissed the concerns, stating, “Can I just correct you? Okay. You use those words. I don't use those words.... And it's, frankly, offensive" (Legislative Assembly of Saskatchewan 2006, 557). 
By any other name, the Framework provides the scaffolding for Saskatchewan's current fire management strategy, also known as "Let-it-Burn." There are two key changes to fire management strategy that are written into the framework that mark a shift from fire suppression to values-protection. The first is a shift towards managing fires based on what are referred to as "Values-at-Risk" (VAR). According to the Framework a "values at risk approach is the foundation of recent changes to forest fire management" (Saskatchewan Environment 2003, 15). VAR are defined as "the specific or collective set of natural resources and man-made improvements / developments that have measurable or intrinsic worth...that could be destroyed or otherwise altered by fire" (ibid, 45). A VAR approach to wildfire management is thus a method of triage, underwritten by an understanding that not all fires are able to be extinguished in a context of high firefighting costs and limited personnel, equipment, and funding. In order to be protected, however, a "value" must either cohere or be made to cohere to the government's values-protection system. The problem of doing so is stated explicitly in the final draft of the VAR Framework:

Assigning worth [to values] is difficult and may result in high expectations from stakeholders and the Aboriginal community. Consideration must be given to: the cost of fire protection compared to the replacement 'value' to be protected; the anticipated effectiveness of the suppression efforts; and any trade-offs that may be required (ibid, 1718.)

VAR, in turn, are a systematized way to determine what values are worth keeping and which ones "do not justify a large expenditure," as a state agency-affiliated study put it (Konopelny 1993, 40). To say some values are expendable is the essence of a VAR-oriented policy. In Saskatchewan, a VAR approach was first suggested in the Saskatchewan Forest Fire Policy Study (1995). The Study was commissioned by the Government of Saskatchewan to understand "the impact of fire on commerce, and the cost/benefit of protecting private property, communities and infrastructure while assuring public safety" following "record levels of activity, expenditures and resources losses" (Saskatchewan Environment 1996, 1) in the 1995 wildfire season. Put otherwise, the purpose of the Study was to determine a new fire strategy that would re-prioritize suppression activities given ongoing "conflict between human activity and the natural role of fire." While perhaps ironically distinguishing fire as a wholly "natural" process, the implementation of the Study's recommendations contributed to the Branch's highly cultural and spatialized strategy for fire reintegration (Table 1).

\begin{tabular}{|l|l|l|}
\hline Wildfire management area & Relevant features & Strategy \\
\hline Primary Timber Area (PTA) & $\begin{array}{l}\text { High value timber, human life, } \\
\text { communities, infrastructure, } \\
\text { values at risk }\end{array}$ & $\begin{array}{l}\text { Provide initial attack and sustained } \\
\text { action to control and suppress fires in high } \\
\text { timber value areas. }\end{array}$ \\
\hline
\end{tabular}




\begin{tabular}{|l|l|l|}
\hline Secondary Timber Area (STA) & $\begin{array}{l}\text { Low value timber (as identified } \\
\text { by forest industry and verified } \\
\text { by Forest Service Branch) } \\
\text { human life, communities, } \\
\text { infrastructure, values-at-risk }\end{array}$ & $\begin{array}{l}\text { Containment of wildfires and prevent } \\
\text { spread to the PTA. Attack if near high } \\
\text { values or PTA. }\end{array}$ \\
\hline $\begin{array}{l}\text { Area North of the Primary } \\
\text { and Secondary Timber Areas } \\
\text { (NTA) }\end{array}$ & $\begin{array}{l}\text { Human life, communities, } \\
\text { infrastructure, other values-at- } \\
\text { risk }\end{array}$ & $\begin{array}{l}\text { "Monitor wildfires and ongoing } \\
\text { assessment of the values-at risk with the } \\
\text { intent to allow wildfire inclusion for } \\
\text { ecological purposes on the landscape." }\end{array}$ \\
\hline
\end{tabular}

Table 1: Wildfire strategies as listed in the "Wildfire Management Operational Policy and Procedure Manual" (Ministry of Environment 2016a, 2, original emphasis).

While the exact location and name of each wildfire management area has shifted over time-due to changes in the Province's forestry objectives and public pushback-the policy has meant that fire's reintegration is limited in the more southern commercial forest and "cottage country" region, but remains the dominant strategy outside of Indigenous communities and areas of low timber value further north (Figure 3).

The second key change in approach-and one that is often used by the Province to legitimize the politics of VAR-involves an institutional and cultural shift towards "Ecosystem Management" (EM) among forestry scientists and their wildfire manager counterparts in the early 1990s (Cameron and Early 2015). As the Framework explicitly states, "Ecosystem management is the second of the two major factors which support this policy... [It] has been defined as the integrated management of natural landscapes, ecological processes, physical and biological components, and human activities to maintain or enhance the integrity of an ecosystem" (Saskatchewan Environment 2003, 4). At the time, forest conservation ecologists considered EM a novel and "holistic approach" to managing resources that would ensure that "ecological services and biological resources are conserved while appropriate human uses are sustained" (Brussard et al. 1998, 9). Doing so involved a shift towards managing human activities, such as forestry, in ways that consider or even promote natural ecological processes, including fires, floods, wind, and insects. The policy Framework explains this shift in thinking, "The traditional way of viewing fire and forest insects and diseases is that they are bad and should be eliminated...Ecologists now recognize that trying to manage individual elements of the landscape is not effective and that fire and insects and disease are part of the dynamics of ecosystems" (Saskatchewan Environment 2003, 4). Re-conceptualized as a complex and resilient ecological system, state forest managers could utilize any number of management strategies to include or even mimic natural disturbances (Neale et al. 2019). 


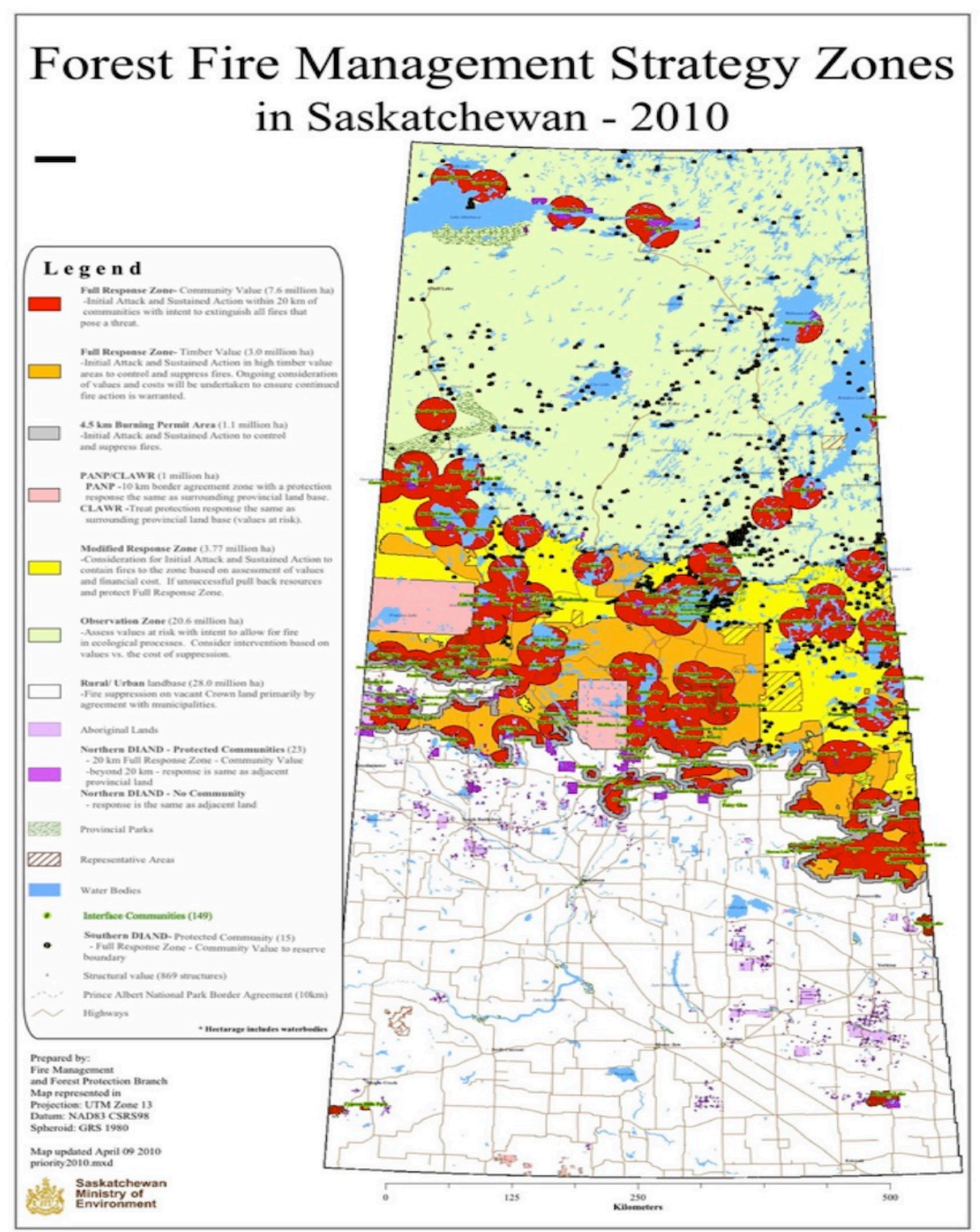

Figure 3: Map of Forest Fire Management Strategy Zones-2010. After public pushback regarding "Let-it-Burn," the term "Observation Zone," which insinuated lack of action, was replaced with the more banal "Area North of the Primary and Secondary Timber Area" or NTA. As of 2018, the most up-to-date map reflects areas from Table 1 and others stated in Government of Saskatchewan 2016a.

In Saskatchewan, EM dominated resource management policies and practices throughout the 1990s, particularly in the areas of forestry and fire management. In 1995, the 
Department explicitly sought to promote "ecosystem-based decision-making," commissioning scientists to create an "Ecoregions of Saskatchewan" map as well as an "Ecological Land Classification System" to help guide government managers (Acton et al. 1998). In 1997, Saskatchewan Environment went through a full rebranding process based on EM (Figure 4), which was by then listed as a guiding principle for the Department.

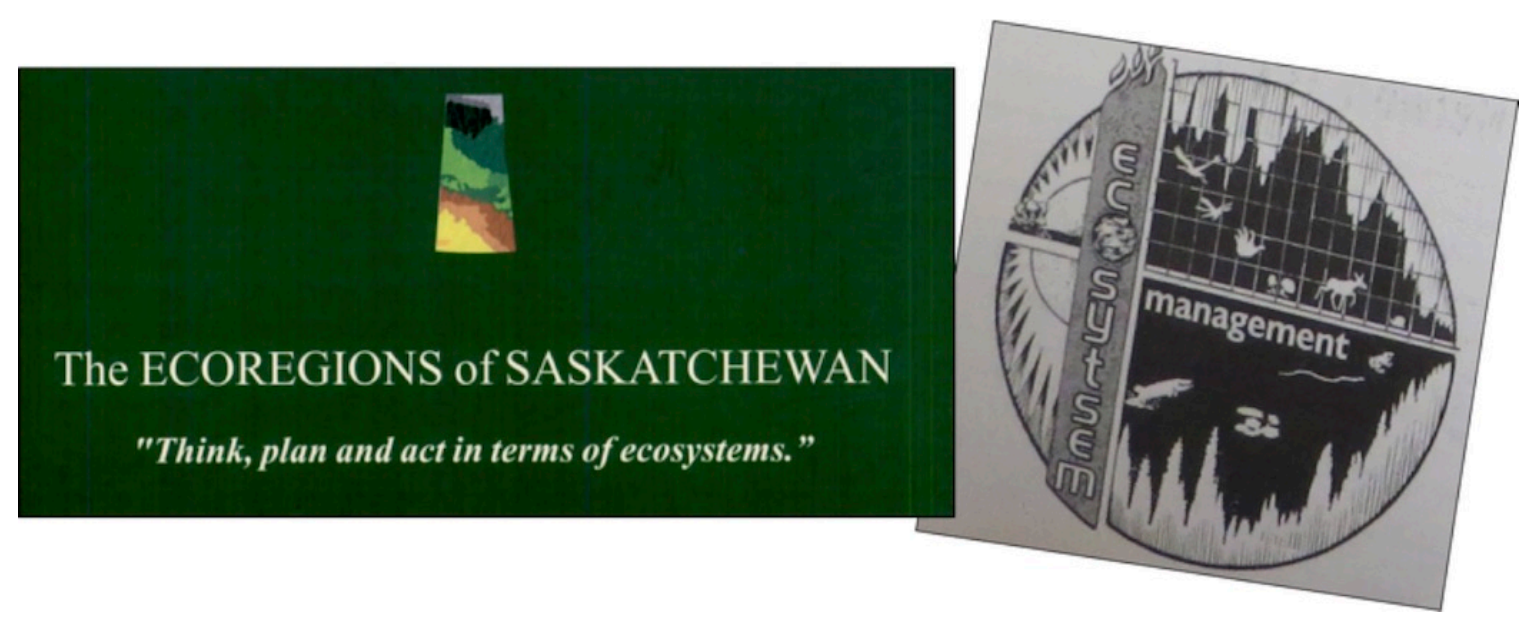

Figure 4: Ecosystem management foregrounded decision-making in the 1990s.

EM was never meant to be understood as an approach aimed at ecological purity," but instead was recognized as a highly cultural and political practice of environmental infrastructuring. As the Framework states "key to promoting fire in ecosystem management is establishing a fire program that is driven by landscape management objectives" (Saskatchewan Environment 2003, 24). Despite this early recognition that fire's re-integration would take place within the Province's larger objectives to manage both lands and people, as I will show, the idea that fire should be reintegrated as a wholly natural component of forest ecology became a key aspect of Departmental messaging regarding "Let-it-Burn." Indeed, a 2016 internal review of the policy concluded that public controversy regarding the approach stemmed from "12 years of [public] misunderstanding...of the operational decisions regarding wildfire renewal in the Boreal Forest" and recommended that the WMB "needs to do a better job of marketing its policies, strategies, and operational decision making processes" (Government of Saskatchewan 2016, 15).

\footnotetext{
- In fact, the conclusion of the Ecoregions of Saskatchewan guide warns against naturalizing EM management towards any specific policy objectives. They write, "Oddly, terms like ecology, ecosystem and ecoregion are not always thought of as holistic concepts... No one owns these words but it is crucial that people understand how they are used by different groups and organizations... What relationships are there between trees and people, or between trees and soils/climate/habitat/land use, or between harvesting timber today and sustaining forests for tomorrow?... [EM] requires an interdisciplinary approach, one that integrates the skills of many different professionals and organizations and transcends departmental mandates" (Acton et al. 1998, 182-183).
} 
Interestingly, the need for the Department "to improve public knowledge and awareness of the role of fire... as natural components of ecosystems, and as tools in ecosystem management" is not new, but written into the very fabric of the Framework, which continues to orient policy today (Saskatchewan Environment 2003, 36). Through this framing, the problem facing wildfire managers is not the policy itself, but a public that misunderstands fire ecology and in turn the policy's intentions. In what follows, I examine the practices associated with "Let-it-Burn," arguing that public pushback stems not from a public deficient in knowledge or trust (Wynne 2006) but from an attunement to practices that materially-remake forest life in ways that cohere with settler values and end goals.

\section{Making and Destroying Forest Relations: Values-at-Risk}

It's August 2018 and I'm at the province's Wildfire Management Branch (WMB), five minute drive outside of Prince Albert along the southern edge of the boreal forest. Today, $I^{\prime} m$ meeting with Andrew, the WMB's Fire Science Specialist. Andrew supervises the Branch's two full-time GIS personnel, who are charged with, among other tasks, updating the WMB's living "values-at-risk" (VAR) map. He also works closely with the Branch's Education and Prevention Coordinator, who has recently begun working with northern communities and First Nations who are leading "fuels mitigation" projects aimed at reducing flammable fuel sources (i.e., cutting down pine or spruce trees) near structures and directly surrounding communities. Fuels mitigation projects have become a key preventative mechanism through which particular aspects of forest life are able to be protected in the context of large fires associated with climate change, settler fire suppression, and more recently "Let-it-Burn." This is all to say that Andrew is very familiar with the ins and outs of how "values protection" is enacted.

In today's meeting, Andrew and I are looking at his computer while he scrolls through a number of images depicting the before and after of "values protection" efforts (Figure 5). Later, he generously e-mails me a number of these images, including at least two labeled "sprinkler success $1 \& 2$." He explains to me the guiding idea behind values protection:

If we can make the community or those structures more resilient to fire, that's what's really going to help to protect and save those places. There are good examples of this up North, and Bruce's got some good images of this-maybe you've seen them. There's this horseshoe of green around them [the value], and it's completely scorched around it. You can't tell me those don't work! As long as you don't lose your water supply, it works."

\footnotetext{
- As of winter 2019, the Ministry of Environment's WMB was combined with the Ministry of Government Relation's Emergency Management and Fire Safety division to form the Saskatchewan Public Safety Agency. While the WMB no longer exists in this name, I use the term to be consistent with the organizational structure at the time when fieldwork was conducted.

10 Wildfire Management Branch officials have been given pseudonyms to point to larger systems and structures rather than individuals.

"Interview, August 17, 2018.
} 


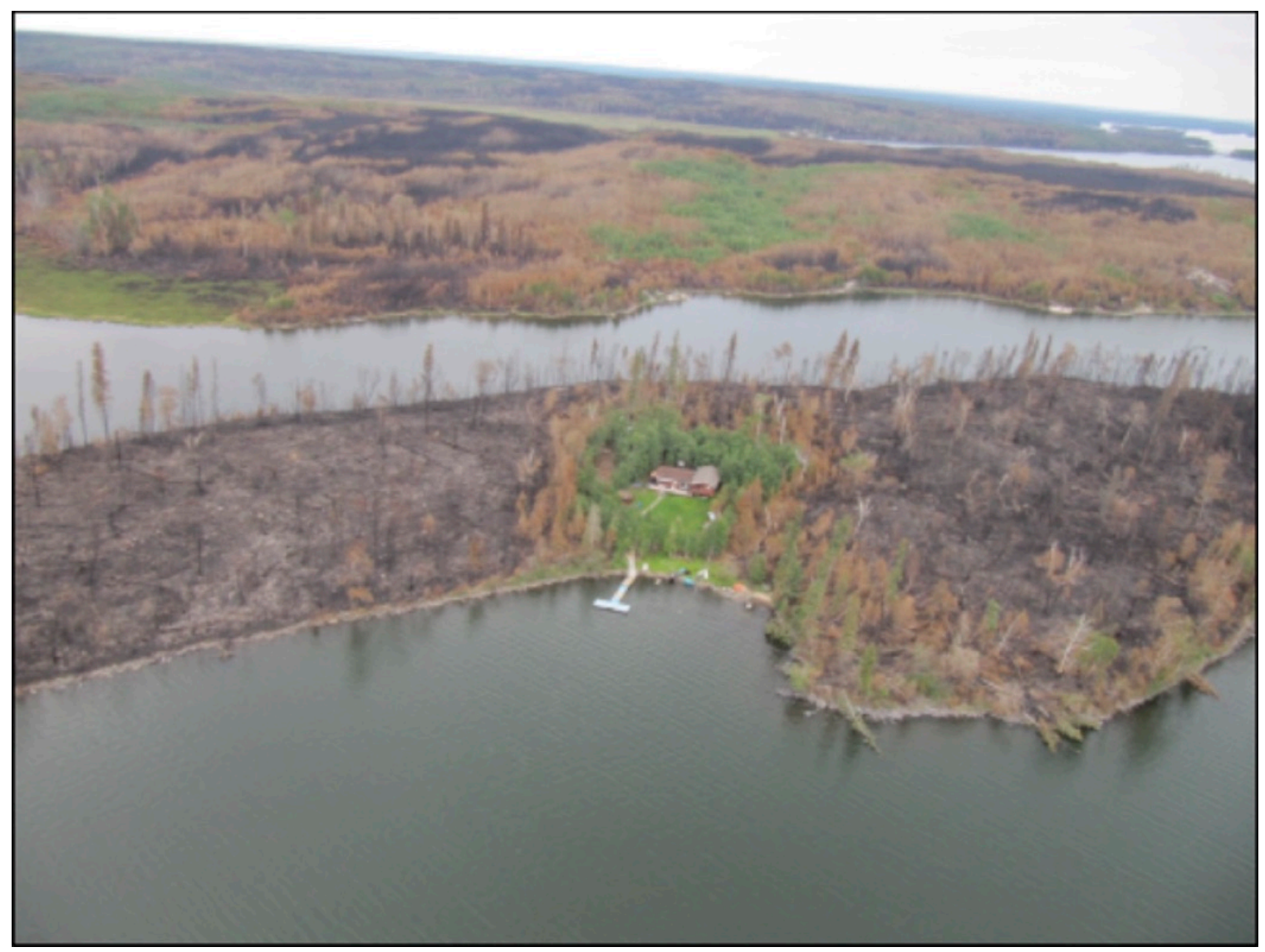

Figure 5: Values protection “success." Photo: Government of Saskatchewan, 2018.

As he shows me these images, I think back to a conversation I had a month earlier with Cliff, the Director of Forests for the Prince Albert Grand Council-a tribal council representing 12 First Nations and 28 reserve communities located throughout the boreal half of the province. Cliff worked as a wildland firefighter for nearly 20 years, first with the provincial government and, in the last few decades, as an instructor training tens of thousands of First Nations and Métis firefighters. Although Cliff is familiar with and trained on values protection, he describes these efforts as in and of themselves insufficient for protecting the values important to many Indigenous northerners. He explains:

If you protect that cabin, you can physically put a sprinkler on it and protect the cabin. But you let everything else burn. Where's the purpose? What's the point in having your cabin? You have no fur. So the next five years or whatever time is going to effect that traditional livelihood of that individual...If there's no old forest left, where do they go to 
get their medicine? So, sure they may have it, but at this point in time, at that location, it's not there. And how long does it take for that moss to replenish itself?

In contrast to Andrew's description of success, Cliff articulates how values protection actually fails to protect forest values when they are conceptualized as a cabin alone. How people exist in relation to the forest-or have come to "use" structural values-is not taken into account when structures alone are protected. In this section, I argue that practices of values protection not only miss the mark in protecting Indigenous values; they also seek to actively reshape forest life in ways that align with Province's economically rationalized, private property-oriented valuesprotection system. Practices of values protection are thus a form and particular version of what Murphy (2018) calls "distributed reproduction" through which specific, often Indigenous, relations and 'values' are constrained while state-sanctioned settler economies, priorities, and futures are enabled to flourish (see also Durocher in Bramadat-Willcock 2020; Davis and Todd 2017).

Métis scholar and wildfire social scientist Amy Cardinal Christianson $(2015,197)$ has remarked that there is often disagreement between settler wildfire agencies and Indigenous people and Nations regarding what counts as a "value" worth protecting. She writes:

One primary difference in wildfire response between wildfire managers and Indigenous peoples is how one would classify "values at risk." Whereas wildfire managers may look at structures, infrastructure and natural resources, an Indigenous person may include archaeological sites, trap lines and traditional hunting areas as values at risk.

Differences in values have long-since been a key issue through which publics have assembled around the "Let-it-Burn" policy. This was brought up, for example, in the initial consultations for the Forest Fire Insect Disease Management Framework, ${ }^{\text {is }}$ and was more recently stated publicly by Prince Albert Grand Council Grand Chief and former wildland firefighter, Brian Hardlotte, who remarked "You need to protect the values and the value to us is the land" (Hicks 2017, n.p.). Land or the specific ways in which humans, animals, plants, and any number of other beings are able to exist in relation to one another-the lifeways through which different values are enacted-are what is at stake in values protection. Here, I turn to state practices and

${ }^{12}$ Interview, July 17, 2018, Cliff Buettner.

${ }_{13}$ Meeting attendees consistently raised doubts about whether the government would or even could sufficiently protect the values important to northerners, stating "you want us to decide what priorities are, and there are too many" (Saskatchewan Environment 2002a: 16) and that there are "over 1000 important historic sites identified by elders in the North." (Saskatchewan Environment 2002b: 22). Others questioned the intent of the policy framework, asking officials whether the government was "putting the commercial forest ahead of a home in the forest?" (19) or "going to change and make economic resources number one?" (30). Nearly all communities emphasized the need to utilize and "reprioritize" (17) local firefighting crews and strategies, arguing that "All the other values depend on tighter control of who the firefighters are" (30). 
protocols of values protection, suggesting that "values" are not just in the heads and hearts of state officials, but infrastructured into the ways in which "values" - and the specific relations that constitute them-are prioritized, identified, stored, and ultimately enacted through Saskatchewan's cultural fire regime.

Within the current values protection process, relations in the boreal forest are destroyed and rebuilt on behalf of the Province in a number of ways that are integral to understanding "Letit-Burn" as a settler fire regime. The process of institutionalizing "good" or "acceptable" externalities is what wildfire scientist Andrew Watson and others (2009) have referred to as the "tradeoffs in values at risk" (2). In Saskatchewan, tradeoffs unevenly impact Indigenous Nations and northern communities located in what the state classifies as the "Area North of the Primary and Secondary Timber Area" (NTA). Here, wildfire strategy emphasizes the "ongoing assessment of the values at risk with the intent to allow wildfire inclusion" (2, original emphasis), involving "protection of remaining values including remote structures and natural resources as determined by the Ministry" (5, my emphasis). According to current provincial government policy, decision-making regarding how and whether values are protected are guided by the following key principles:

- A wildfire priority and response strategy will be selected with the intent to minimize the economic impact of wildfire on regional and provincial economies [and]

- The wildfire response strategy efforts and anticipated expenditures should be proportionate with the values being protected (Ministry of Environment 2016a, 5).

Unlike other public emergency services, such as municipal firefighting, then, the provincial wildfire agency determines its decisions to protect values at least in part through a cost/benefit analysis, whereby firefighting costs and resources are compared to the benefit of protecting a particular value. The benefit or worth of that value (e.g. trappers cabins, a local fishery operation, or even sacred sites) is determined by a local fire base manager and, depending on the dollar amount of a particular strategy put forward, by those in upper management who themselves are responding to Ministry mandates. How an economy, or a particular constellation of relations that allow for particular beings to flourish, are selected for protection is based on the following "directives":

- Primary residences are considered a higher priority than remote recreation or secondary structures.

- Large industrial or commercial sites important for supporting provincial or regional economies are considered a higher priority than singular commercial enterprises.

- Commercial timber identified by the Ministry, as important for regional economies, will be a higher priority than remote recreation/secondary structures (ibid, 6).

In these instances, then, primary residences (or houses), large industrial or commercial sites and certain areas of commercial timber are protected, while "remote recreation or secondary structures" - such as hunters or trappers cabins - that may be essential for local and family 
economies, are considered low priority and thus rendered expendable by the state contingent on particular wildfire characteristics. The result, as a recent report from the Assin'skowitiniwak (Rocky Cree) community of Pelican Narrows put it, is "widespread concern about the 'Let it Burn' policy of the government, which is locally interpreted as a means to prioritize southern 'white' values over northern Indigenous ones" (Poole et al. 2020, vii-viii).

A second way that "Let-it-Burn" functions to constrain and produce forest life involves the ways in which 'other values' must involve a relationship with a structure, and preferably a private property relation in order to be protected. This, in part, relates to the technologies and protocols through which these values are stored and protected. The VAR database is an interactive GIS interface, where different values are entered through predetermined categorical inputs. As STS scholar Sybille Lammes $(2017,1021)$ explains, "Both digital maps and analogue maps can be viewed as cartographical interfaces, or points of contact, which are "consulted" and through which spatial relations are understood and produced." That is to say, how a user interface is designed impacts what spatial arrangements and relations are included or externalized in the process of values protection. Lucy, the head of Policy at the Branch, described the Province's VAR database to me as follows:

I think the best distillation I've ever heard from someone who hasn't seen the database is when you see an ad for a house for sale. That's what it looks like. You've got a page that says-“here's a picture of it [the value], here's where it's located, here's who owns it. Here's everything about it." Not how much it costs-we don't put that on there. We have pictures of it, we know where it is. ${ }^{14}$

Individual ownership and a "value" being a structure located in a single, unmoving location shared with the state $e^{i s}$ are among the assumptions that characterize relations of "value" in the current values-protection database-an understanding and limitation of VAR that has been raised by tribal governments in terms of what is able to be protected (Welch 2012). Once entered, relations of values are enacted as VAR through their classification into predetermined categories: industrial (e.g. "a mine site"เ); commercial (e.g., "an outfitter"); Crown, (e.g. provincial power lines or cell towers); recreational (e.g., "anybody's cabins"); or traditional (e.g., "Treaty cabin used for traditional hunting or fishing") uses. When I asked a GIS personnel responsible for inputting values into the system about whether non-structural values, such as traplines, would be included as a "value" for protection, I was told this would only be the case if they were directly

\footnotetext{
${ }^{14}$ Interview, July 27, 2018.

${ }^{15}$ Currently, the largest source of "values" is the Province's perhaps aptly named "Lands" Branch. As Ron, a Fire Base Manager, explained to me, "whether they're cabins, or outfitting camps, fishing camps, or mines, they're supposed to go through a permitting process. That information should filter back to us, and then we plot those [values] onto our maps so that we have that information." Interview, August 2, 2018. Values that cannot be shared with the settler state (e.g., sacred sites or unregistered cabins) and thus cannot be protected when values-at-risk databases are developed and run by the Province alone.

${ }^{16}$ Interview, August 24, 2018.
} 
associated with a cabin." In this process of entering values into the database, certain relations are made legible or worthy of protection, while others become decontextualized. A trappers cabin might be protected, though it's use may be lost.

Specific relations between humans and structures are likewise infrastructured within protection practices. For example, a relation between humans and structures as one of private property-limited to human-object ownership-is written directly into the Standard Operating Procedures for values protection. Firefighters are told to "as soon as possible" contact "the lease/property owner... to inform him [sic] of the situation, and to enable him to remove any property he may wish to protect" (Ministry of Environment 2016b, 1). After this, crews are advised that "all property and equipment upon the site is private, and should not be touched, removed or used without the authorization of the owner." Finally, "Ministry personnel shall advise the lease/property owners that wildfire operations are part of the Ministry mandate... [and they] will be discouraged from engaging in wildfire suppression activities." Explicit in the operating procedures for values-protection, then: values are structures that can be protected using sprinkler systems; most "values" are privately owned or leased-and that in itself is the relationship being protected; and lastly, the values being protected aren't contingent on their use or protection by the owners or community members who are themselves assumed to be evacuated (Poole et al. 2020). If, as Eve Tuck and K. Wayne Yang $(2012,5)$ have argued, "In the process of settler colonialism, land is remade into property and human relationships to land are restricted to the relationship of the owner to his property," then VAR is one way through which property relations are allowed to flourish.

Overall, in the enactment of Saskatchewan's settler fire regime, values, and lifeways are input into VAR, and violently re-made in ways that align with the WMB's particular understanding and valuation of forest relations. That is to say, through VAR's differentially violent acts of care (Murphy 2015), practices of alterlife that do not adhere to the settler government's supposedly universal visions for fire and forest living are made incoherent and thus destroyed through fire's reintegration. As the study out of Pelican Narrows put it:

[B]y allowing the fires to burn, traditional lands, traplines, animals, medicinal plants, and so on, are destroyed, compromising the community's ability to use their traditional territory. This indicates a fundamental difference between provincial and northern Cree values regarding the land and its resources (Poole et al. 2020, 38, my emphasis).

This is not to say that the values prioritized by the Ministry are of no interest to Indigenous residents. They are. But the types of relations and economies that do not adhere to, or are incommensurable with, government priorities are burned over and their ability or agency to maneuver within a settler colonial system is compromised (Liboiron 2017). In the context of late industrialism, the uneven "failures" and "successes" of "Let-it-Burn"-the conflicting visions

${ }^{17}$ Interview, August 2, 2018. Paraphrasing by request. 
presented by Cliff and Andrew-are not new but part of existing systems of settler extraction and property-making through onto which settler-agency practices of fire reintegration map.

\section{Compounding Ecologies of Settler Colonialism}

A second way that we can think of the "Let-it-Burn" controversy is its premise of ecological purity. If alterlife involves "Refusing narratives of purity, or a sense of life as separate from its conditions" (Murphy 2018, 118), then here I suggest that the WMB's framing of "Let-it-Burn" fires as natural functions to deny the conditions and systems through which fire and forestrelations are enmeshed. If protection of values is the crux of the "Let-it-burn" policy, then narratives of purity aim to naturalize those values within the forest landscape.

Current practices of fire reintegration are increasingly justified in terms of moving towards "natural" ecological processes and conditions. The guidelines for managing fire on the WMB's public website, for example, state that "Wildfire is a natural and essential ecological process in Saskatchewan's boreal forests. Healthy and vibrant forests are naturally renewed by fire, or through forest harvesting that mimics the patterns of natural fire" (Government of Saskatchewan n.d., my emphasis). In a context where a century of fire suppression intersects with anthropogenic climate change, the WMB's calls to return "natural" fire processes via "Let-itBurn" may be particularly unconvincing to those who have experienced ecological disruptions in the forest. As Chief Peter Beatty of Peter Ballantyne Cree Nation explained to me, "You can't really depend on nature to take its course. It's not an argument that really stands up to any kind of scrutiny. If they [Wildfire Management] believe that things haven't changed in the last 20 years or 30 years, they're not thinking right." "s Rather than not understanding fire ecology, Chief Beatty and others questioning "Let-it-Burn" understand but disagree with the policy's central premise, namely, that wildfires act as they always have and that the provincial government alone might contain them from the things that northerners value most.

An effect of current and historical wildfire management practices is that wildfires impact life in increasingly unpredictable ways. As a policy brief written by the New North Association of Northern Saskatchewan Communities $(2013,6)$ put it, "Let-it-Burn" "assumes that the natural environment is still in a pre-colonization state; wildlife habits and habitats have radically changed, so that natural burning may not necessarily have the same benefit it once did." Indeed, scientific studies have remarked that extreme mega fires taking place on contemporary landscapes are not comparable to those recorded historically. As Eisenberg et al. $(2019,2)$ have noted:

Recent wildfires have exhibited record size, more extreme fire behavior, and higher severity...Today, large wildfires threaten ecosystem function and conservation because of interaction among pervasive stressors such as climate change, invasive species, and land-

${ }^{18}$ Interview, July 11, 2018, Chief Peter Beatty, Peter Ballantyne Cree Nation and Prince Albert Grand Council Wildfire Management Task Force. 
use, as well as management changes, resulting in no-analog ecosystems and the erosion of ecological memory.

In this sense, fires occurring "naturally" through lightning or by other means do not burn in natural ways, but would more aptly be considered as "already altered, which is also life open to alteration" (Murphy 2017, 497).

Accordingly, the "Let-it-Burn" policy's largescale, high-intensity fires impact plants and animals differently than before, and-conditioned through ongoing processes of settler colonialism and state resource extraction-often in ways that negatively impact the lives and livelihoods of Indigenous northerners. This includes, for example, the economic costs associated with having to close local businesses due to smoke warnings and evacuations (NITHA 2018), but also in the non-consensual severing of relationships with plant and animal life. The latter was explained to me by Richard, the Commissioner of Saskatchewan First Nations Emergency Management and Vice-President of the Aboriginal Firefighters Association when discussing the impacts of "values protection" on PAGC member nations:

Within our communities-the values-at-risk are, in that area of the forest is where we harvest caribous. And that area of the bush is where we harvest our medicines and where we harvest our fish and where we harvest our berries and mushrooms and everything else. That's not really taken into consideration in most cases. And when a fire affects that value-at-risk for the First Nations, it causes extreme hardships. They have to go hunting into the Northwest Territories all of a sudden to get their food for their community-or into a different province. ... That's their grocery store out there. ${ }^{19}$

The example of caribou, mentioned by Richard, is a specific concern that has been raised by many Cree, Dene and Métis people for whom caribou is important for food, clothing, and cultural practices. Caribou eat lichen and when lichen disappear due to fire, caribou leave-a phenomenon that fire ecologists are trying to better understand, but is likely increasing as more severe and intense wildfires burn through topsoil (Joly et al. 2009; Kolden and Rogan 2013). In this sense, the effect of "Let-it-Burn" fires is both relational and bodily and takes place in ways that are unevenly felt, particularly in the northern regions of the province. ${ }^{\cdots}$ More fire or at least the kind of high intensity fire caused by "allowing" wildfires to burn "naturally" is precisely the kind of fire that will act in unknown ways.

Importantly, the ecological changes associated with "Let-it-Burn" wildfires cannot be viewed in isolation from a compounding cycle of settler colonial induced ecological change that has impacted Indigenous lives and ecologies over centuries. For example, in questioning the supposed "natural" environment through which "Let-it-Burn" is expected to function, Chief

${ }^{19}$ Interview, August 16, 2018, Richard Kent.

${ }^{20}$ Indeed the Province's caribou management plan divides the boreal forest into two main regions coinciding with the northern "Let-it-Burn" boundary to account for "considerable fire disturbance" (Government of Saskatchewan 2019, 16). 
Beatty contextualizes contemporary forest ecologies within compounding factors of industry-led fire suppression and anthropogenic climate change. He argues:

You can't depend on nature taking its course. I mean, if that was the case, we should have never started trying to suppress fires. But I think we-you know, when you think back, it was because of the forestry companies. They wanted to preserve the big trees, the big forest, the old growth forest, so they could mill it into lumber. Like I said, it's not a real solid argument to let nature take its course...That argument about "let nature take its course" has an economic and financial cost associated with it. And it's a very high cost. ${ }^{21}$

Here, Chief Beatty critiques the WMB's continued naturalization of "Let-it-Burn" as a supposedly ecologically "pure" process of fire's reintegration. Rather, "Let-it-Burn," is itself a culturally-mediated process of restructuring forest life-one that takes place in and through a forest forever changed by settler fire management, climate change, and alterlife. Ignoring this reality is not only illogical, but produces a "high cost" of harm as Indigenous economic and social relations are disrupted.

The shifting cultural landscapes enacted through "Let-it-Burn" are understood and responded to within the larger historical context of settler colonial ecological disruptions and genocide. Changes in fire regimes have been linked with an introduction of small pox in the $18^{\text {in }}$ century (Van Wagner et al. 2006), and in Saskatchewan, an earlier "caribou crisis" was caused by settler mineral explorers lighting fires for the purposes of provincial resource exploitation in the 1930s. As historian Stephen Pyne (2007) has written:

The geography and scale of burning through old regimes stirred the land into turmoil. It especially upset the arrangement of traditional hunting and trapping grounds, and where a lichen-feeding, migratory species such as caribou was involved it could deflect the seasonal movement of herds. This alteration could ripple through Native [sic] economies with devastating effects... What the province gained from mineral exploitation it lost from traditional economies (293).

When I interviewed Elder George Morin, member of PAGC's newly implemented Wildfire Management Task Force, he likened the high intensity burning of forests associated with "Let-itBurn" to the massacring of buffalo by settlers in the 1800s-an event that radically disrupted ecologies and life in what is now prairie Saskatchewan guided by genocidal policies and practices predicated on settler government dependency and resource exploitation. He explains, "They burn up your rights. That's the first thing they do. They destroyed all of the buffalo down South of our brothers and sisters. They were at the mercy of the government. They [settlers] destroyed their livelihood, their economy and everything." ${ }^{\prime 2}$ In this way, the ecological restructuring of the north caused by "Let-it-Burn," is not a new phenomenon but what Kyle Powys Whyte (2016b,

${ }^{21}$ Interview, July 11, 2018.

${ }^{22}$ Interview, July 11, 2018. 
118) refers to as colonial déjà vu, "part of a cyclical history situated within the larger struggle of anthropogenic environmental change catalysed by colonialism, industrialism and capitalism." Practices of fire reintegration aimed at ecological purity actively ignore the compounding cycle of non-consensually disrupted forest relations that have been experienced, felt, and responded to by Indigenous people.

While the government frames the "Let-it-Burn" controversy as resulting from a public misunderstanding about the natural role of fire in forest ecology, this "public" continues to reject "Let-it-Burn" as a process of violent cultural landscaping led by "provincial cuts to wildfire fighting funding and staffing, policies guiding when action should be taken on fires, and a lack of collaboration with First Nation communities" (Walker et al. 2020, 133). In this way, the provincial government's attempts to cool down the "Let-it-Burn" controversy by describing fire as "natural" actively side steps the highly political ways in which "Let-it-Burn" disrupts and restructures forest lives and livelihoods, particularly for Indigenous residents. Indeed, the Province's aims at restoring the forest to some "natural" state, might be understood as a "settler move to innocence," an "attempt to deny and deflect their own complicity" (Tuck and Yang 2012, 10) by placing the effects of settler colonialism's ecological disruption in the past rather than constitutive of historical and contemporary burning regimes and economic policies that guide "natural" fires in the present. In a context of historical and ongoing ecological disruption and rebuilding, how, then, might institutionalized fire management practices go forward in a good way?

\section{Managing Fire in Alterlife}

I'm sitting with Chief Beatty in a hotel restaurant in kistahpinanihk/Prince Albert, Saskatchewan. We've just had a lengthy conversation about the "Let-it-Burn" policy, including shared frustrations about the Province continually denying the policy's existence. After a short while, I present what I felt was a possible solution to the issue:

This is my rose-colored glasses version-but it seems like wildfire management's job should be to protect community interests. So then you would go and ask the communities, "For you, what's a value?" And then you protect whatever they say. That seems like how I'd think about it. ${ }^{23}$

He responded with a short "yes" and we continued our conversation, where he began telling me about the ongoing work of the Northern Inter-Tribal Health Authority (NITHA) - a First Nations-led-and-directed multiband organization focused on providing culturally-based, locally relevant health services. Since its inception, NITHA has focused a lot on wildfires. In the last five years, Pat, the organization's Emergency Response Coordinator, has started using satellite imagery to detect the location of wildfires. The satellite imagery is obtained from

${ }^{23}$ Interview, July 11, 2018. 
MODIS-a US Department of Forest Service sponsored program that provides up-to-date geospatial data regarding the location of fires in North America through the use of NASA satellites. It is used by most fire management agencies in the United States and Canada, including the Saskatchewan WMB. Pat superimposes MODIS fire data onto a map indicating legal jurisdiction of each northern and First Nation community, including relevant contact information for local mayors, Chief and Council members, first responders, health care providers, firefighters and more. Included in his map are First Nations-specific "values," directly entered by local Chiefs, emergency coordinators and other community members. This information is not shared inter-tribally but is kept in specific databases used by each Nation. The MODIS imagery updates every 15 minutes, and, in turn, Pat checks the location of fires "you know, six or seven times a day" ${ }^{24}$ and measures the movements of fire "eight times a day. Just in case that information is going to be requested." The location of a fire is then shared with tribal emergency response coordinators and Chiefs, many of whom have requested multiple daily updates. When I later asked Pat how this project came about, he explained, "It came out of trying to get that strategic information... and seeing very quickly that either the information quality that they [First Nations governments] are getting or the frequency of the information that they're getting wasn't serving the information needs of our elected officials." By providing information specifically designed for the use of different First Nations, Chiefs are able to begin mobilizing resources, ensuring their communities, values, and other relations are protected.

While the existence of NITHA is contingent on external funding-and emergency response is currently run by a staff of five-it is an example of First Nations self-determination, of rebuilding practices taking place in the context of "Let-it-Burn." A key difference between the vision I initially presented and the one embodied by NITHA is the question of who should be directing decision-making practices that impact the lives and livelihoods of Indigenous people on Indigenous territory. While the option I presented involves the inclusion of Indigenous knowledge as "supplemental" value within existing systems (Whyte 2017)—asking, "how can your ideas add to our established approach?" (Neale 2020, np) — the latter prioritizes the ability of Indigenous Nations to exercise political sovereignty over their lands and futures, to govern and enact new systems entirely. As settler colonial and Indigenous studies scholars have shown, doing so is necessary for ecological repair in settler colonial contexts, and may take place through or beyond partnerships with the state (Coulthard 2014; Beckett and Keeling 2018).

Ensuring Indigenous Nations' right and ability to exert sovereignty in their territories through wildfire management is a way forward that ensures that fire reintegration (if desired) contributes to, rather than negates, Indigenous rebuilding and resurgence. This is the vision for wildfire management Chief Beatty presents to me later in our conversation:

I would like to see our own First Nations people, especially in each of our traditional areas...be given the possibility of protecting our own values. Having the ability to train our own people, whether they're forest fire suppression workers, or forestry workers,

${ }^{24}$ Interview, July 19, 2018, Patrick Hassler. I thank Patrick for reviewing statements written about NITHA. 


\begin{abstract}
biologists, whatever. But we should have that responsibility-to protect our own. Same as Lac La Ronge [Indian Band]. They should be able to protect their own [values]. Any of our First Nations should be able to do that, especially within the general area of our immediate traditional territories for each community...That's what I would like to see. That we're funded properly and given the resources to do that. I think we would do a very good job of that. And you know what? Then we can sit with our Elders and our professional people. There's two sides to the work-not sides, but sources of information. There's the Elders and they're experienced from prior years and then you have the young people that are trained, that are taught in universities, know how to work computers, and so on and so forth. If you combine those two things. You're going to come up with something that's going to work for northern Saskatchewan. And whether it's full fire suppression or something else, I think with the support of the communities, you can come up with something that is going to be this [the right thing]. Those are my rose-colored glasses. Whether that will ever happen in my life time, I don't know. I certainly would like to see that..$^{25}$
\end{abstract}

Chief Beatty and other Indigenous leaders are envisioning-and moving towards- a future for wildfire management, whereby Indigenous Nations assert control and direction over decision-making practices that impact their lands and people. He does not shut down the possibility of reintroducing fire entirely, but rather points to the need to restructure the way fire reintegration is done, by whom, and on whose terms. Doing so necessarily involves a variety of First Nations expertise, including the ecological and firefighting expertise of Indigenous Elders and youth working as GIS personnel, forecasters, biologists, and more. What is being built is not a future that envisions a return to ecological purity, nor does it frame Indigenous contributions as solely "local" or "traditional" (Cameron 2012; Thomassin et al. 2019). Rather it presents a future that contends with the messiness of alterlife and that "acknowledges that one cannot simply get out" but presents an "openness to alteration... to become something else, to defend and persist, to recompose relations to water and land" (Murphy 2017, 324). This is what Indigenous northerners have been asserting throughout the "Let-it-Burn" policy's existence-from asserting their "very strong desire... [of] influencing policy and eventually delivering the program" (Saskatchewan Environment 1996), to the ongoing work of NITHA and other First Nations organizations. These are actions of asserting sovereignty over one's bodies and lands, now, and into the future.

Indigenous people in northern Saskatchewan have always lived with and managed fires, though the particular method through which this is done has changed both through and in spite of settler colonialism. Alongside the changing forest ecologies caused by settler colonialism's violent uprooting of fire regimes, many Indigenous people in northern Saskatchewan became actively involved in both state and Indigenous Nation-led firefighting practices in their home territories. In the late 1950s, the Province began recruiting and conscripting Indigenous firefighters and "depended heavily on them for manual labor on fire lines" (Quiring 2004, 170). In

${ }^{25}$ Interview, July 11, 2018. Words in brackets were verified with Chief Beatty prior to publishing. 
addition to becoming frontline firefighters, many Indigenous firefighters became part of specialized firefighting teams known as "Smokejumpers" - the first of their kind Canadawhereby crews parachuted into remote areas, attacking fires before other recruits arrived on the ground. In 1992, the Saskatchewan First Nation Forest Fire Protection Services Agreement was signed, making Saskatchewan the first province in the country to have an official agreement for forest fire protection with First Nations and the federal government-a process initiated by First Nations to ensure their members had the training and ability to fight fires near and outside of their communities. As of 2018, there are at least 58 First Nations contract crews and 22 Métis and Northern Community work crews, most of whom were trained by Indigenous instructors contracted by the PAGC. Many are third- or fourth-generation firefighters who are hired by the WMB.

Despite large-scale expertise, participation, and leadership in wildfire management, Indigenous participation within decision-making has largely been restricted to "a dialogue about their vulnerability and their values at risk" (Sherry et al. 2019, 500). This is because within contemporary wildfire management discourse and literature, there is often a juxtaposition between Indigenous people, knowledge, and fire suppression-what I suggest stems from a faulty distinction that links Indigeneity and "good" land management through ideas of ecological purity (Neale 2018). For example, when speaking of a similar "Let-it-Burn" controversy that took place between Dene and Métis Nations and the Government of the Northwest Territories in the 1980s, environmental historian of fire Stephen Pyne (2007, 392) described a "weird, historic reversal" in which "environmentally attuned officials campaigned for fire's accommodation, while Native [sic] groups argued for fire's exclusion" - what he attributed to a "vortex of identity politics" rather than active pushback against a settler fire regime. Rather than reversing history, solutions being proposed by Indigenous organizations stem from an intimate awareness of it. As a report by the PAGC- Wildfire Management Task Force $(2018,2)$ recently put it, "Mutual dialogue is critical for joint solutions to fighting fires in northern Saskatchewan. Northern Indigenous peoples have historic experience with the suppression of wildfires and must be given opportunities to provide input on strategies as well as to document traditional knowledge perspectives. “

When I speak to Indigenous people involved in firefighting today, many tell me that modern wildfire fighting and management are themselves Indigenous knowledge. When they say this, I believe them. Fire suppression became, and continues to be, an important way through which Indigenous northerners are able to live and work in the Boreal forest, supporting family and land relations (New North 2013). In the context of residential schools, some have told me that they did not get to speak or learn their native languages until working for the $\mathrm{WMB}$, overseeing

${ }_{26}$ See also Miller 2010. I have not asked what is meant by this, but here I think of Indigenous knowledge in the way Sisseton-Wahpeton Oyate scholar Kim TallBear, defines it, "as any knowledge that helps us survive as Peoples" $(2017,3)$. This does not discount important relationships specific to cultural burning, but encompasses all types of knowledge that helps contribute to Indigenous sovereignty and self-determination, which may include involvement in wildfire management and fire suppression. 
both settler and Indigenous firefighting crews and teams. Here, language holders could meet in the evenings or between shifts, sharing language via a compromised institution, wherein English remains mandatory for on-the-job communication..$^{2}$ Doing so reflects the messiness of alterlife: how relations persist and thrive both through, in spite of, and against the structures that condition life in what is currently northern Saskatchewan. Management practices based on an illusion of purity that place Indigenous culture, interests, and sovereignty in the past or cosigned solely to the category "traditional" fail to address these relations.

\section{Conclusion}

Across the globe, settler nation-states like Canada, Australia, and Brazil are being forced to contend with the large-scale ecological and social disruptions caused by settler colonialism. Wildfires are a charismatic example of this that beg the question: how to burn well in ecologically compromised lands? As is seen in the case of Saskatchewan's "Let-it-Burn" policy, many solutions being proposed to deal with ecological disruptions are amenable to institutions, not because they are central to respecting Indigenous sovereignty and relations, but rather because they work well within existing systems. If late industrialism has taught us anything, it's that these systems fail unevenly precisely because of the logics through which they are built. So while "Let-it-Burn" policies of fire reintegration may seem like a contrast to historical fire suppression, both may be guided by a settler colonial logic that understands "good" human-forest relations as one of natural resource extraction and private property ownership above all else. Although Indigenous northerners have actively engaged in nearly a century of rebuilding alongside fire suppression and the success of provincial fire and forestry efforts is indebted to them, this ultimately matters very little to institutions whose foundations of modernity, universalism, and ecological purity are premised on their erasure. Forests that were once made pure by denying Indigenous cultural burning are now purified through fire's reintegration. Examples of Indigenous alterlife are burned over, not because they aren't known about by disaster management institutions, but because the compromises they come to embody are incoherent to them.

How, then, should wildfire institutions manage fire in a time of alterlife? I started this paper by noticing my breath. Breath-the itchy feeling I felt in my lungs- not only attuned me to my environment, but it afforded me with decisions to make. Do I move indoors? Do I grab my inhaler? Do I leave town? These decisions, and the possibilities therein, are not innocent. They are conditioned through my own compromised relationships, including issues of access, wealth, whiteness, and chronic illness. The decisions I make will also be compromised, but responded to via an understanding of my own embodied relations, my obligations to them, and how these might be impacted. For those people living in the northern forest area, $90 \%$ of whom are

\footnotetext{
${ }_{27}$ Anonymous firefighting instructor. Story shared with permission, 14 May 2019. He noted that while
} English language use is currently firefighting protocol, this could be otherwise. 
Indigenous, the reintegration of fire via "Let-it-Burn" is attuned to not just through environments and bodies more prone to wildfire smoke, but through disruption of people's community and economic livelihoods, including land relations-what cannot and should not be dealt with by settler institutions alone. In late industrialism, proposed solutions to wildfire and any other number of issues, then, are best solved, not by institutions working under the premise of purity or supposed universal (settler) values, but through partnership and leadership of those whose relations are effected by systems designed to fail them. For settler governments working on Indigenous lands, this necessarily means ensuring that environmental management practices respect the sovereignty and self-determination of Indigenous Nations (Lake et al. 2017; Bilbao et al. 2019), including their inherent and Treaty rights (Morin 2017). In Saskatchewan, Indigenous governments are already putting forward such a project. In 2018, the PAGC released their Wildfire Management Task Force Interim Report that advocated for "the development of a First Nations wildfire advisory council" (PAGC 2018,2) to help in overseeing wildfire operations. Advisement would include all aspects of wildfire management-not just the location of Indigenous "values," but also how VAR databases are created, how to partner with Indigenous organizations, and, ultimately, how (and whether) fire should be returned to Indigenous territories.

If processes of fire reintegration involve "set[s] of actions and processes that ignite new relationships between humans and landscapes" (Sutherland 2019, 783), it's important to consider the futures being built through them. Are the relationships being built or severed through fire consensual? Do they take into account the many relationships, livelihoods, and ecological processes rebuilt during fire's absence? And in reintegrating fire, whose histories are erased or made "innocent?" These are the questions that need to be answered locally and should dictate, how, if, and on whose terms fire should be used as a management approach. What this looks like and how this is done is always context, Nation, and community specific. This is why Indigenousled fire management in what is currently Australia may look like cultural burning, while for some Nations in what is presently Saskatchewan, it may look like fire suppression.

\section{Author Biography}

Alex Zahara (he/him) is a settler scholar from kistahpinanihk/Prince Albert, and a $\mathrm{PhD}$ Candidate in the Department of Geography at Memorial University of Newfoundland. His dissertation research 'Settler Fire Management' examines the history and culture of wildfire management in northern Saskatchewan with a focus on settler colonialism in alignment with Indigenous, feminist, and queer thinkers. Alex is trained in biology, STS, and settler colonial theory and his research focuses on living well in polluted or otherwise compromised landscapes. $\mathrm{He}$ is a co-editor of Discard Studies, a member of Civic Laboratory for Environmental Action Research (CLEAR), and the 'Northern Exposures' research team. 


\section{Acknowledgements}

Research for this paper was conducted in kistahpinanihk on Treaty 6 Territory, the traditional homelands of Woodland Cree, Plains Cree, Swampy Cree, Rocky Cree, Dene, Dakota, and Métis people. Ongoing help and thoughtful feedback was provided throughout this project by Robin McLeod, Matt Heley, Elder George Morin, Chief Peter Beatty, Cliff Buettner, Arn Keeling, Max Liboiron, Lianne Leddy, and Nicole Power. I am thankful to employees of the Saskatchewan Wildfire Management Branch who provided me with a number of research materials and who agreed to be interviewed for this project. Terry-Lynn and Rick Zahara provided logistical and intellectual support. I am thankful for additional feedback from: cultural fire lab members Timothy Neale, Will Smith, Aadita Chaudhury; Dean Bavington and students from the undergraduate course Geog. 3610: Cultural Landscapes at Memorial University; and the thematic collection editors, Ali Kenner and Chloe Ahmann. Peter Friedrichsen, Caitlynn Beckett, Kirsten Reid, and Ignace Schoot provided crucial research ethics advice, editing, and organizational support. Generous and thoughtful feedback was provided by ESTS editor Katie Vann and three anonymous reviewers. Financial support was provided through a Social Science and Research Council of Canada (SSHRC) Doctoral Award, SSHRC Insight Grant (award number: 435-20140968), and the Northern Scientific Training Program.

\section{References}

Acton, D., Padbury, G., Stushnoff, C., Gallagher, L, Gauthier, D., Kelly, L., Radenbaugh, T., and J. Thorpe. 1998. The Ecoregions of Saskatchewan. Regina, SK: Canada Plains Research Center/Saskatchewan Environment and Resource Management.

Bramadat-Willcock, M. (2020). "'Let it burn': Suicide prevention policy likened to wildfires." National Observer, August 13. Accessed 13 August 2020. https: / / www.nationalobserver.com/2020/08/13/ news/ let-it-burn-suicide-preventionpolicy-likened-wildfires

Beckett, C., and A. Keeling. 2019. "Rethinking remediation: Mine reclamation, environmental justice, and relations of care." Local Environment 24(3): 216-230.

Bilbao, B., Mistry, J., Millán, A., and A. Berardi. 2019. “Sharing Multiple Perspectives on Burning: Towards a Participatory and Intercultural Fire Management Policy in Venezuela, Brazil, and Guyana." Fire, 2(3): 39.

Bourke, M., Atkinson, A., and T. Neale. 2020. "Putting Country back together: a conversation about collaboration and Aboriginal fire management." Postcolonial Studies, 1-6.

Brussard, P., Reed, J. and C. Tracy. 1998. "Ecosystem management: what is it really?" Landscape and Urban Planning 40 (1-3): 9-20.

Cameron, E. S. 2012. "Securing Indigenous politics: A critique of the vulnerability and adaptation approach to the human dimensions of climate change in the Canadian Arctic." Global Environmental Change, 22(1): 103-114.

Cameron, L., and S. Earley. 2015. "The ecosystem-movements, connections, tensions and translations." Geoforum, 65: 473-481. 
Christianson, A. 2015. "Social science research on Indigenous wildfire management in the 21st century and future research needs." International Journal of Wildland Fire 24(2): 190-200.

Coulthard, G. 2014. Red Skin, White Masks: Rejecting the Colonial Politics of Recognition. Minneapolis, MN: University of Minnesota Press.

Davis, H., and Z. Todd. 2017. "On the importance of a date, or, decolonizing the Anthropocene." ACME: An International Journal for Critical Geographies, 16(4): 761-780.

Eisenberg, C., Anderson, C., Collingwood, A., Sissons, R., Dunn, C., Meigs, G., Hibbs, D., Murphy, S., Kuiper, S., SpearChief-Morris, J., Little Bear, L., Johnston, B and C. Edson. 2019. "Out of the ashes: Ecological resilience to extreme wildfire, prescribed burns, and indigenous burning in ecosystems." Frontiers in Ecology and Evolution, 7.

Gan, R. W., Ford, B., Lassman, W., Pfister, G., Vaidyanathan, A., Fischer, E., Volckens, J., Pierce, J. R. and S. Magzamen. 2017. "Comparison of wildfire smoke estimation methods and associations with cardiopulmonary-related hospital admissions." GeoHealth 1(3): 122-136.

Government of Saskatchewan n.d. Wildfire Operations. Available online: https:/ / www.saskatchewan.ca/residents / environment-public-health-andsafety/wildfire-in-saskatchewan/wildfire-operations Accessed 20 November 2019.

Government of Saskatchewan. 2016. Wildfire Management Strategic Framework. Power Point Presentation. Regina, SK: Government of Saskatchewan.

Government of Saskatchewan. 2019. Range Plan for Woodland Caribou in Saskatchewan: Boreal Plan Ecozone- SK2 Central Caribou Administration Unit. Regina, SK: Government of Saskatchewan.

Haraway, D. J. 2016. Staying with the trouble: Making kin in the Chthulucene. Durham, NC: Duke University Press.

Hicks, G. 2017. “No 'Let it Burn' Wildfire Policy: Wildfire Management." SaskNow, October 31. Accessed 21 October 2019. https://sasknow.com/2017/10/31/no-let-it-burn-wildfirepolicy-wildfire-management/

Ingalsbee, T. 2017. "Whither the paradigm shift? Large wildland fires and the wildfire paradox offer opportunities for a new paradigm of ecological fire management." International Journal of Wildland Fire 26(7): 557-561.

Joly, K., Jandt, R.R. and D.R. Klein. 2009. "Decrease of lichens in Arctic ecosystems: the role of wildfire, caribou, reindeer, competition and climate in north-western Alaska." Polar Research 28(3): 433-442.

Kenner, A. 2018. Breathtaking: Asthma care in a time of climate change. Minneapolis, MN. University of Minnesota Press.

Kimmerer, R. W. and F. K. Lake. 2001. "The role of indigenous burning in land management." Journal of Forestry, 99(11): 36-41.

Kolden, C.A. and J. Rogan. 2013. "Mapping wildfire burn severity in the Arctic tundra from down sampled MODIS data." Arctic, Antarctic, and Alpine Research 45(1): 64-76.

Konopelny, P. 1993. An Evaluation of Manitoba's Forest Fire Preparedness System. Master's Thesis, Winnipeg, MB: University of Manitoba. 
Konsmo, E. M. and K. Recollet. 2019. "Meeting the land(s) where they are at: A conversation between Erin Marie Konsmo (Métis) and Karyn Recollet (Urban Cree)." In Indigenous and decolonizing studies in education: Mapping the long view, edited by L. T. Smith, E. Tuck, \& K. W. Yang, 238-251. New York, NY: Routledge.

Lake, F. K., Wright, V., Morgan, P., McFadzen, M., McWethy, D. and C. Stevens-Rumann. 2017. "Returning fire to the land: celebrating traditional knowledge and fire." Journal of Forestry. 115(5): 343-353.

Lammes, S. 2017. “Digital mapping interfaces: From immutable mobiles to mutable images." New Media \& Society 19(7): 1019-1033.

Le, G. E., Breysse, P. N., McDermott, A., Eftim, S. E., Geyh, A., Berman, J. D., and F. Curriero. 2014. "Canadian forest fires and the effects of long-range transboundary air pollution on hospitalizations among the elderly." ISPRS International Journal of Geo-Information, 3(2): 713731.

Legislative Assembly of Saskatchewan. 2006. Standing Committee on the Economy: Hansard Verbatim Report, No. 32. Regina, SK: Government of Saskatchewan.

Lewis, M., Christianson, A., and M. Spinks. 2018. "Return to flame: reasons for burning in Lytton First Nation, British Columbia." Journal of Forestry, 116(2): 143-150.

Liboiron, M. 2017. "Compromised agency: The case of BabyLegs." Engaging Science, Technology, and Society, 3: 499-527.

Liboiron, M. 2018. “Waste colonialism.” Discard Studies, November 1. Accessed 1 November 2018. https: / / discardstudies.com/2018/11/01/waste-colonialism/

Liboiron, M. 2021. Pollution is Colonialism. Durham, NC: Duke University Press.

Massie, M. 2010. At the Edge: the North Prince Albert Region of the Saskatchewan Forest Fringe to 1940. Doctoral dissertation, Saskatoon, SK: University of Saskatchewan.

Miller, A. M., Davidson-Hunt, I. J., and P. Peters. 2010. "Talking about fire: Pikangikum First Nation elders guiding fire management." Canadian Journal of Forest Research, 40(12): 22902301.

Ministry of Environment. 2016a. SOP Name: Wildfire Management Strategies and Priorities, SOP\# OPS311.1. Regina, SK: Government of Saskatchewan.

Ministry of Environment. 2016b. SOP Name: Values Protection- Sprinklers, SOP\#: OPS311.4. Wildfire Management Operational Policy and Procedure Manual. Regina, SK: Government of Saskatchewan.

Morin, G. (Elder). 2017. Peter Ballantyne Cree Nation North Eastern Saskatchewan Wildfires. Peter Ballantyne Cree Nation.

Murphy, M. 2015. “Unsettling care: Troubling transnational itineraries of care in feminist health practices." Social Studies of Science 45(5): 625-641.

Murphy, M. 2017. "Alterlife and decolonial chemical relations." Cultural Anthropology 32(4): 494503.

Murphy, M., 2018. “Against population, towards alterlife." In Making Kin Not Population. Edited by A. Clarke and D. Haraway, 101-124. Chicago, IL: Prickly Paradigm Press. 
Neale, T. 2018. "Digging for fire: Finding control on the Australian continent." Journal of Contemporary Archaeology 5(1): 79-90.

Neale, T. 2020. "What are whitefellas talking about when we talk about "cultural burning"?." Inside Story, 17 April. Accessed 20 April 2020. https://insidestory.org.au/what-arewhitefellas-talking-about-when-we-talk-about-cultural-burning/

Neale, T., Zahara, A. and W. Smith. 2019. "An eternal flame: the elemental governance of wildfire's pasts, presents and futures." Cultural Studies Review 25(2): 115-134.

New North. 2013. Wildfire: Brief Overview and Talking Points. La Ronge, SK: New North.

NITHA. 2018. 2015 Northern Saskatchewan Wildfire Study. Prince Albert, SK: Treppel Consulting.

Norgaard, K. 2019. Salmon and Acorns Feed our People. Newark, NJ: Rutgers.

Northern Trappers Alliance. 2014. "Trappers Block Oil Companies in Northwestern Saskatchewan." The Media Co-Op, November 19. Accessed 5 November 2019. http:// www.mediacoop.ca/newsrelease/32223

PAGC. 2018. Fighting Forest Fires in Northern Saskatchewan: Task Force Interim Report. Prince Albert, SK: Prince Albert Grand Council.

Poole, M., Merasty, J., \& J. Waldram. (2020). "Like Residential Schools All Over Again" "tāskoc kitimāhtāsowi kiskinwahamākewin asaminna": Experiences of Emergency Evacuation from the Assin'skowitiniwak (Rocky Cree) Community of Pelican Narrows. Saskatoon, SK: University of Saskatchewan.

Pyne, S. 1997. World Fire: The Culture of Fire on Earth. Seattle, WA: University of Washington Press. Pyne, S. 2007. Awful Splendour-A History of Fire in Canada. Vancouver, BC: UBC Press.

Quiring, D. 2004. CCF Colonialism in Northern Saskatchewan: Battling Parish Priests, Bootleggers, and Fur Sharks. Vancouver, BC: UBC Press.

Saskatchewan Environment. 1996. Forest Fire Policy Study- 1995. Regina, SK: Government of Saskatchewan.

Saskatchewan Environment. 2002a. Fire and Forest Insect and Disease Policy Development Report on Phase 1 Consultations. Regina, SK: Government of Saskatchewan.

Saskatchewan Environment. 2002b. Fire and Forest Insect and Disease Policy Development Report on Phase 2 Public Consultations. Regina, SK: Government of Saskatchewan.

Saskatchewan Environment. 2003. Fire and Forest Insect and Disease Management Policy Framework Document. Regina, SK: Government of Saskatchewan.

Saskatoon StarPhoenix. 2015. "Province denies 'let it burn' policy." Saskatoon StarPhoenix, July 5. Accessed 4 February 2020. https: / / thestarphoenix.com/news/ province-denies-let-it-burnpolicy

Sherry, J., Neale, T., McGee, T.K. and M. Sharpe. 2019. "Rethinking the maps: a case study of knowledge incorporation in Canadian wildfire risk management and planning." Journal of environmental management 234: 494-502.

Smith, L. T. 2012. Decolonizing methodologies: Research and indigenous peoples. London, UK \& New York, NY: Zed Books Ltd.

Smith, W. 2020. Mountains of Blame: Climate and Culpability in the Philippine uplands. Seattle: University of Washington Press. 
Sutherland, C. R. 2019. “Encountering the burn: Prescribed burns as contact zones." Environment and Planning E: Nature and Space, 2(4): 781-798.

TallBear, K. 2014. "Standing with and speaking as faith: A feminist-indigenous approach to inquiry." Journal of Research Practice, 10(2): N17-N17.

TallBear, K. 2017. "Kim Tallbear: Future Imaginary Dialogues (transcript)", 3 March 2017, $\begin{array}{lllll}\text { Concordia } & \text { University. } & \text { Accessed } & 12 & \text { March }\end{array}$ http: / / indigenousfutures.net/outputs / future-imaginary-dialogues /

Thomassin, A., Neale, T. and J. Weir. 2019. "The natural hazard sector's engagement with Indigenous peoples: a critical review of CANZUS countries." Geographical Research, 57(2): 164-177.

Todd, Z. 2017. "Fish, kin and hope: Tending to water violations in Amiskwaciwâskahikan and Treaty Six Territory." Afterall: A Journal of Art, Context and Enquiry, 43(1): 102-107.

Tsing, Anna. 2015. The Mushroom at the End of the World: On the Possibility of Life in Capitalist Ruins. Princeton and Oxford: Princeton University Press.

Tuck, E. 2009. "Suspending damage: A letter to communities." Harvard Educational Review, 79(3): 409-428.

Tuck, E., \& Yang, K. W. 2012. "Decolonization is not a metaphor." Decolonization: Indigeneity, Education \& Society, 1(1): 1-40.

Van Wagner, C. E.., Finney, M. A., and M. Heathcott. 2006. “Historical fire cycles in the Canadian Rocky Mountain parks." Forest Science, 52(6): 704-717.

Walker, H. M., Reed, M. G., and A. J. Fletcher, A. 2020. "Wildfire in the news media: An intersectional critical frame analysis." Geoforum, 114: 128-137.

Watson, A., Matt, R., Waters, T., Gunderson, K., Carver, S., and B. Davis. 2009. "Mapping tradeoffs in values at risk at the interface between wilderness and non-wilderness lands." In Gonzalez-Caban, Armando, tech. coord. Proceedings of the Third International Symposium on Fire Economics, Planning, and Policy: Common Problems and Approaches. Gen. Tech. Rep. PSW-GTR-227 (English), 375-387. Albany, CA: US Department of Agriculture, Forest Service, Pacific Southwest Research Station.

Welch, R. 2012. "Effects of fire on intangible cultural resources: moving toward a landscape approach." In Wildland Fire in Ecosystems: Effects of Fire on Cultural Resources and Archaeology, edited by KC Ryan, AT Jones, CL Koerner, KM Lee, 157-170. Fort Collins, CO: USDA Forest Service, Rocky Mountain Research Station, General Technical Report RMRSGTR- 42.

Whyte, K. P. 2016a. "Indigenous experience, environmental justice and settler colonialism." In Nature and Experience: Phenomenology and the Environment. Edited by B. Bannon, 157-174. Lanham, MD: Rowman and Littlefield.

Whyte, K. P. 2016b. "Is it colonial déjà vu? Indigenous peoples and climate injustice." In Humanities for the Environment. Edited by J. Adamson and M. Davis, 102-119. New York, NY: Routledge. 
Whyte, K. P. 2017. “What Do Indigenous Knowledges Do for Indigenous Peoples?" in Keepers of the Green World: Traditional Ecological Knowledge and Sustainability. Edited by M.K. Nelson and D. Shilling, 57-81. Cambridge, UK: Cambridge University Press.

Whyte, K.P. 2018. "Settler colonialism, ecology, and environmental injustice." Environment and Society 9(1): 125-144.

Wolfe, P. 1999. Settler colonialism and the transformation of anthropology. New York, NY: Cassell.

Wynne, B. 2006. "Public engagement as a means of restoring public trust in science-hitting the notes, but missing the music?" Community Genetics 9: 211-210.

Your Forest. 2019. “Welcome to Good Fire." 3 September. Accessed 18 August 2020. Available online: https://yourforestpodcast.com/good-fire-podcast/2019/9/2 / welcome-to-goodfire. 